\title{
Effect of symbiosis in the production of melon seedlings with arbuscular mycorrhizal fungi
}

\author{
Efecto de la simbiosis con hongos micorríticos arbusculares en la producción de \\ plantines de melón
}

\author{
Christian Santander ${ }^{1,2 *}$, Jorge Olave $e^{1,2}$
}

\begin{abstract}
This research was performed in a semi-controlled greenhouse of the "Estación Experimental Canchones", in which the evolution of the effect of the mycorrhizal fungi over the growth parameters, differentiation, biomass, stress indicators and biochemical indicators for the production of the horticultural seedlings; and the percentage of mycorrhization obtained was evaluated. Inodorous type honeydew melon was used as the plant model. The mycorrhizal fungus Glomus intraradices Schenk and Smith, commercially known as MYCOSYM TRITON, was used for the inoculation at the moment of sowing with doses of 0; 20; 40 and 80 spores per plant. A completely randomized design was used; analysis used a factorial analysis variance (ANOVA) with the a posteriori LSD, using the statistical software INFOSTAT and an alpha value of 0.05 . The results obtained in the destructive sample on the $50^{\text {th }}$ day after sowing showed that the treatment with 40 spores per plant produced maximum root biomass, low etiolation index, a high value of the proportion of dry root weight to dry shoot weight. However, the activity of both endogenous and induced enzymes of nitrate reductase measured in the leaves was unaffected. We conclude that the symbiotic association between the roots of the melon plants and the mycorrhizal species Glomus intraradices produced a greater root biomass and very favorable conditions for transplanting.
\end{abstract}

Key words: Glomus intraradices, arbuscular mycorrhiza, Cucumis melo, seedling.

\section{RESUMEN}

Esta investigación fue realizada en un invernadero semicontrolado de la Estación Experimental Canchones, donde se evaluó el efecto de los hongos micorríticos sobre los parámetros de crecimiento, diferenciación, biomasa, indicadores de estrés y bioquímicos para la producción de plántulas hortícolas, así como también el porcentaje de micorrización obtenido. El material vegetal utilizado fue melón cv. Honeydew tipo Inodorus. El hongo micorrítico utilizado fue Glomus intraradices Schenk y Smith, nombre comercial MYCOSYM TRI-TON, el cual fue inoculado al momento de la siembra con las siguientes dosis 0; 20; 40 y 80 esporas por planta respectivamente. Se utilizó un diseño completamente aleatorizado, realizándose un análisis de varianza multifactorial (ANOVA) y para la separación de medias se empleó el test LSD, mediante el software estadístico INFOSTAT a un $\alpha=0,05$. Los resultados obtenidos en el muestreo destructivo a los 50 días de siembra determinaron que el tratamiento inoculado con 40 esporas por planta presentó una mayor producción de biomasa radical, menor índice de ahilamiento y una mayor relación peso seco raíz-peso seco vástago; sin embargo, la actividad de la enzima nitrato reductasa endógena e inducida medida en las hojas no fue afectada. En esta investigación se concluye que la asociación simbiótica entre las raíces de las plántulas de melón y las micorrizas de la especie Glomus intraradices determinó una mayor producción de biomasa radicular y una condición más favorable para el trasplante.

Palabras claves: Glomus intraradices, micorrizas arbusculares, Cucumis melo, semilleros.

\section{Introduction}

Microbiota plays an important role in agriculture since it contributes to soil fertility, improving soil structure and biodiversity and has a real effect on plant development (Avis et al., 2008). Among these microorganisms are the symbiotic mycorrhizal fungi, which allow the plants to explore a greater useful surface of the soil by the production of external mycelia connected to the root system, increasing the absorption of nutrients and water, while the fungus receives carbonated compounds from photosynthesis which are necessary to complete its life cycle (Azcón-Aguilar y Barea, 1980; Harley y Smith, 1983; Pereira et al., 1999).

One of the main effects of mycorrhizae is the improvement in the nutritional state of the plants, increasing the capture of phosphorus, calcium,

\footnotetext{
Centro de Investigación y Desarrollo en Recursos Hídricos.

Universidad Arturo Prat, Casilla 121, Iquique, Chile.

* Autor por correspondencia: Christian.Santander@ciderh.cl
}

Fecha de Recepción: 26 Mayo, 2012.

Fecha de Aceptación: 10 Junio, 2012. 
copper, sulfur, zinc and iron; Smith et al. (2001) confirmed the absorption of two nitrogenous forms ${ }^{-} \mathrm{N}-\mathrm{NO}_{3}{ }^{-}$and $\mathrm{N}-\mathrm{NH}_{4}{ }^{+}-$from the soil solution and their transfer to the associated plants. Based on this information, the objective of this study was to evaluate the effect of arbuscular mycorrhizal fungi on the architecture, biomass production, stress tolerance and synthesis of nitrate reductase in seedlings of the Inodorus type honeydew melon.

\section{Materials and Methods}

The research was performed in a semi-controlled greenhouse of the Canchones Experimental Station. The trial used cv. Orange Flesh of Inodorus type honeydew melon, called "melon tuna" in Chile, and included a period of 50 days after sowing. At planting, the mycorrhizal fungus Glomus intraradices was inoculated using the commercial MYCOSYM Tri-Ton MYCOSYM International AG (Switzerland), which contains latent spores at a concentration of 150 spores per gram. Seedlings were grown in thermoforming plastic trays with 72 cells with a capacity of $43 \mathrm{cc}$ each, on a table $40 \mathrm{~cm}$ above the ground. The substrate used was a mixture of peat:Perlite 70:30; seeds were sown homogeneously at a depth of $1 \mathrm{~cm}$. From the emergence of the cotyledons to the first leaf plants were irrigated with water. After the formation of the first leaf we applied a $1 / 3$ concentration of fertirrigation, after the second leaf $2 / 3$, and after the formation of the second leaf with the complete concentration (Table 1). The nutritive solution was adjusted to a $\mathrm{pH}$ of 6.0-6.5; electrical conductivity of $1.6 \mathrm{dS} \mathrm{m}^{-1}$, equivalent to a osmotic potential ( $\Psi$ s) of $-0,067 \mathrm{Mpa} . \mathrm{pH}$ and E.C. were measured every three days to adjust the frequency and time of irrigation.

Inoculation was performed together with sowing. We evaluated four doses ( 4 treatments); $0 ; 20 ; 40$ and 80 spores plant ${ }^{-1}$, using each tray as a treatment; each cells was a pseudo-replicate ( 72 cells). We took destructive samples of five plants of each treatment 50 days after sowing. We determined the percentage of mycorrhization of the roots using the method of Phillips and Hayman (1970) with some modifications, and calculated the degree of mycorrhization using the method of Trouvelot (Trouvelot et al., 1986). We evaluated the physical parameters tissue differentiation, production of dry biomass (leaf, stem and root), stem diameter, plant height, etiolation index and leaf surface, and the stress indicators specific leaf surface (SLF) and the ratio root dry weight to stem dry weight (RDW/SDW).

The biochemical parameters evaluated were the enzymatic activities of endogenous and induced nitrate reductase. For endogenous activity we used the method of Bar-Akiva et al. (1970), adapted by Valenzuela et al. (1987) and determined induced activity using the method of Bar-Akiva and Sternbaum in 1966, modified by Bar-Akiva et al., (1970) and adapted by Valenzuela et al. (1987). Color intensity was measured at $540 \mathrm{~nm}$ in a SPECTRONIC model GENESYS 2 spectrophotometer. A calibration curve was constructed in the range of 0 to $4 \mu \mathrm{M}$, using $\mathrm{NaNO}^{-2} 1 \mathrm{mM}$; the results were expressed in $\mu \mathrm{M}$ $\mathrm{NO}^{-2} * \mathrm{~g}^{-1} \mathrm{pf} \mathrm{h}^{-1}$.

The experimental design was completely randomized. Analysis employed factorial ANOVA with LSD a posteriori tests, using the software INFOSTAT and $\alpha=0.05$. The number of leaves was $\log$ transformed using $\log _{10}(\mathrm{X}+1)$; percentage values were transformed with the Arcsine Transformation.

\section{Results and Discussion}

\section{Percentage of mycorrhization}

Inoculation with different doses of $G$. intraradices spores in melon seedlings produced significant differences in the percentage of mycorrhization (Figure 1). The greatest percentage was observed with 40 spores plant ${ }^{-1}\left(\mathrm{~T}_{2}, 49.8 \%\right)$, followed by $\mathrm{T}_{3}$ $\left(80\right.$ spores plant $^{-1}$ ) with $36.3 \%$ and $\mathrm{T}_{1}$ (20 spores plant $^{-1}$ ) with $16.9 \%$. The mycorrhization response

Table 1. Fertirrigation solution (meq $\mathrm{L}^{-1}$ ) used in honeydew melon (Inodorus) seedlings.

\begin{tabular}{lcccccccc}
\hline Solutions & $\mathrm{H}_{2} \mathrm{PO}_{4}^{-}$ & $\mathrm{NO}_{3}^{-}$ & $\mathrm{SO}_{4}^{-}$ & $\mathrm{K}^{+}$ & $\mathrm{Ca}^{2+}$ & $\mathrm{Mg}^{2+}$ & $\mathrm{NH}_{4}^{+}$ \\
\hline $\mathrm{DN}^{1}$ & 1.25 & 7.50 & 2.50 & 3.25 & 5.00 & 2.50 & 0.5 \\
\hline
\end{tabular}

\footnotetext{
${ }^{1}$ Steiner modified (Casas, 2005); solution adjusted for concentrations of $\mathrm{Cl}^{-} \mathrm{y} \mathrm{Na} \mathrm{Na}^{+}$present in salty irrigation water.
} 


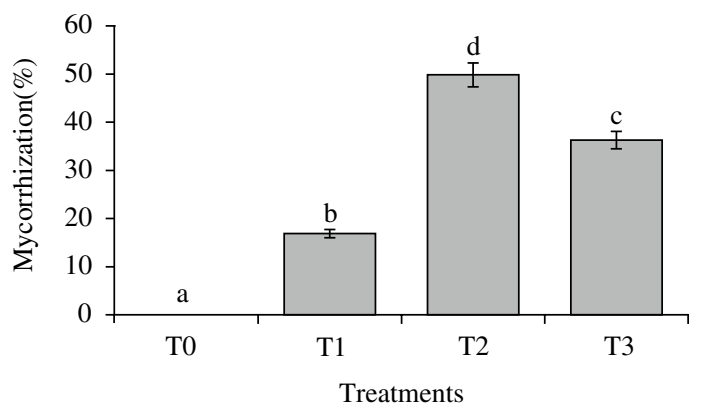

Figure 1. Percent of mycorrhization in roots of Inodorus var. Honeydew melon 50 days after inoculation with $G$. intraradices. Different letters indicate significant differences (LSD, $\mathrm{p}<0.05)$.

with different doses of $G$. intraradices reached a maximum and then decreased (Figure 2), indicating that there is an optimum concentration of $G$. intraradices near 40 spores plant $^{-1}$, and that greater concentrations do not increase the percentage of mycorrhization. Similar results were obtained in tomato cv. Mara by Mujica and Medina (2008), in which there was no further increase after doubling the dose of Glomus mosseae and Glomus Hoi-like. Anaya et al. (2009) also obtained the best response in tomato seedlings inoculated with EcoMic (Glomus fasciculatum) at a medium dose.
Wang et al. (2010), obtained results similar to those reported here with treatment $\mathrm{T}_{2}$ they inoculated seedlings of melon cv. 901 and 908 with $10 \mathrm{~g}$ of substrate containing spores of different mycorrhizae, obtaining after 45 days $39.89 \%$ for Glomus versiforme and $51.75 \%$ for Glomus mosseae (cv. 901) and $46.38 \%$ for G. versiforme and $57.08 \%$ for $G$. mosseae (cv. 908); there were different percentages of mycorrhization between both fungal species and melon cultivars. Contrasting results were reported by Huang et al. (2011), who found 70\% mycorrhization in seedlings of $\mathrm{cv}$. Zhongmi 3 melon inoculated with G. intraradices, and Martínez-Medina et al. (2011), who reported only $8 \%$ mycorrhization of seedlings of cv. Giotto inoculated with Glomus intraradices.

The highest percentage obtained in this study inoculating cv. Honeydew melon with Glomus intraradices was $49 \%\left(\mathrm{~T}_{2}\right)$, which shows that even different cultivars of a species have different degrees of mycorrhization when inoculated with the same fungal species. This agrees with the results of Wang et al. (2010), indicating that the success of plant symbiosis is based on the adequate establishment, development and extension of symbiotic mycorrhizal; this depends on the fungal species and its genetic characteristics, the environment in which it was isolated and its affinity with the plant species

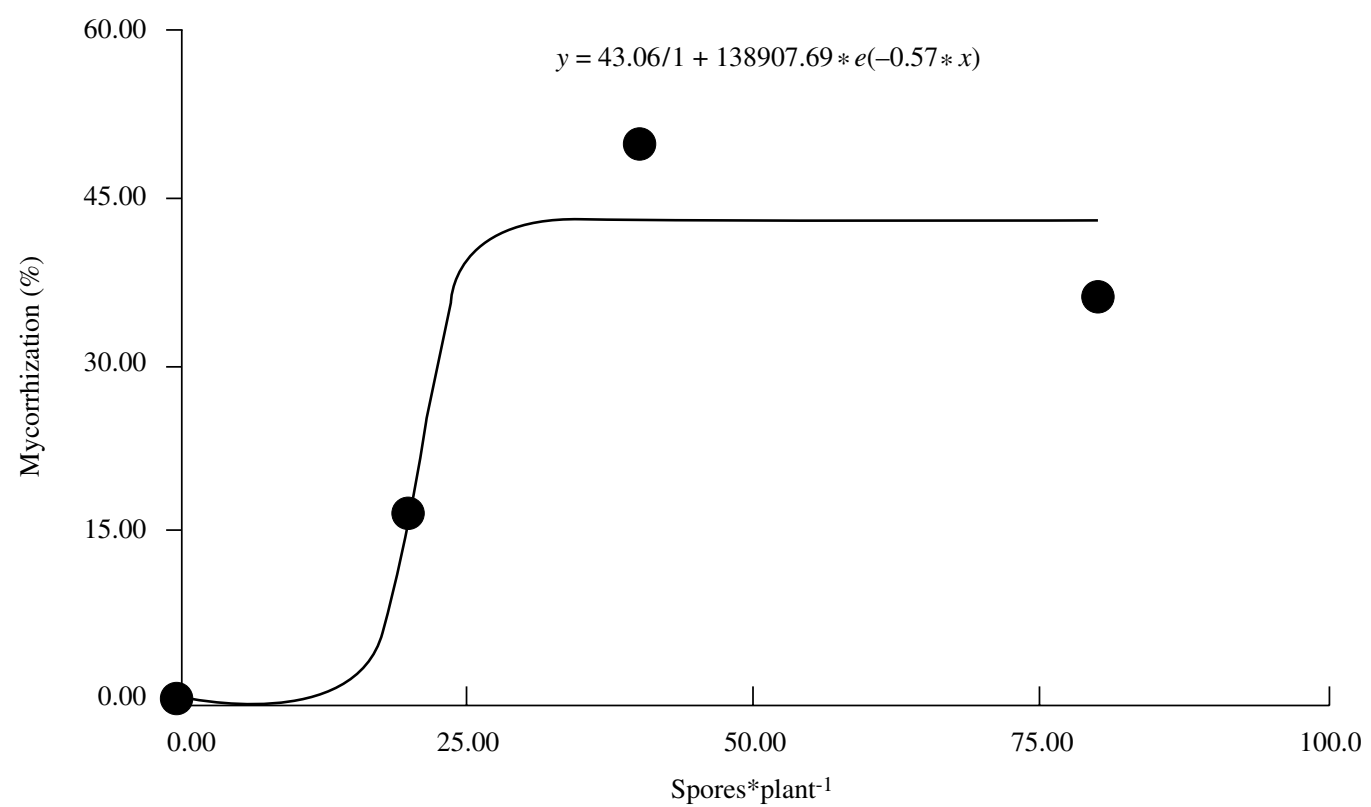

Figure 2. Effect of the dose of spores of $G$. intraradices on the percentage of mycorrhizal colonization in roots of melon Inodorus var. Honeydew 50 days after sowing. 
and/or cultivar. Other factors which influence symbiosis include the physiology of the plants and the properties of their roots (Brundrett, 2002, Drew et al. 2006); these authors reported that the mycorrhizal colonization process is determined by the capacity of soil exploration, which is greater in Glomus mosseae than in G. intraradices.

\section{Growth, differentiation and biochemical parameters}

\section{Biomass production}

Inoculation with $G$. intraradices did not affect the production of leaf biomass, stem or total biomass (Table 2). The main effect was produced in the production of dry root biomass; the differences among treatments were highly significant $(\mathrm{p}=0.0001)$; treatment $\mathrm{T}_{2}$ had the greatest dry weight with $0.21 \mathrm{~g}, 31.25 \%$ and $75 \%$ greater than $\mathrm{T}_{3}$ and $\mathrm{T}_{1}$, respectively, and $133 \%$ greater than the control. The differences in the production of total dry mass were not significant.

Mycorrhization of melon seedlings with Glomus intraradices produced a descending movement of photosynthates, coinciding with Wu et al. (2006) who reported that the mycorrhizal fungus generated a basipetal movement of photosynthates towards the roots. This movement is generated principally by the interchange of nutrients between the fungus and the plant; the hyphae of the fungus increase the effective root system and provide the plant with nutrients outside the depletion zone, while the plant transports carbohydrates towards the root which provide a substrate for the growth and development of the fungus. It has been observed that the greater the level of mycorrhization, the greater the fungal demands for substrate, producing greater movement of photosynthates.

The mycorrhization of the seedlings stimulated root growth; there was $4 \%$ more accumulation of dry material compared to the control, coinciding with the results of González-Monterrubio et al. (2005), who reported a significant increase of $59.2 \%$ in dry root biomass of Opuntia streptacantha seedlings inoculated with mycorrhizal fungi, and with those Huang et al. (2011), who obtained a significant increase by inoculating melon seedlings.

Mycorrhization produced more vigorous plants after transplanting, confirming the proposal for Tessi (1991) and Hoyos (1996), who proposed that greater accumulation of dry material in seedlings makes them more resistant to transplant. Tessi (1991) suggested that a $1 \%$ increase in seedling dry material increases the percentage of rooting by $30 \%$, while Oseni et al. (2010), proposed that an increase in root weight in plants with mycorrhizae produces a positive correlation with nutrient absorption and a better post-transplant response, expressed as greater plant growth.

\section{Parameters of growth and differentiation}

The only significant difference in leaf differentiation and growth parameters was in the etiolation index $(p=0.0340)$. The melon seedlings inoculated with 40 spores plant ${ }^{-1}$ had a more equilibrated distribution between height and diameter (IA: 25.89) compared to seedlings inoculated with 20 and 80 spores plant ${ }^{-1}$ and the control, which had 6\%, 26\% and $52 \%$ more disequilibrium, respectively. Although there were no significant differences in the majority

Table 2. Production of dry biomass in Inodorus var. Honeydew melon seedlings 50 days after sowing, inoculated with $G$. intraradices.

\begin{tabular}{lcccc}
\hline \multirow{2}{*}{ Treatments } & \multicolumn{3}{c}{ Parameters } \\
\cline { 2 - 5 } & LDW $(\mathrm{g})$ & SDW $(\mathrm{g})$ & RDW $(\mathrm{g})$ & TDW $(\mathrm{g})$ \\
\hline T0 & $0.47 \mathrm{a}$ & $0.2 \mathrm{a}$ & $0.09 \mathrm{a}$ & $0.76 \mathrm{a}$ \\
$\mathrm{T} 1$ & $0.33 \mathrm{a}$ & $0.16 \mathrm{a}$ & $0.12 \mathrm{~b}$ & $0.61 \mathrm{a}$ \\
T2 & $0.49 \mathrm{a}$ & $0.17 \mathrm{a}$ & $0.21 \mathrm{~d}$ & $0.87 \mathrm{a}$ \\
T3 & $0.41 \mathrm{a}$ & $0.18 \mathrm{a}$ & $0.16 \mathrm{c}$ & $0.75 \mathrm{a}$ \\
$\mathrm{p}$ & $\mathrm{ns}$ & $\mathrm{ns}$ & 0.0001 & $\mathrm{~ns}$ \\
\hline
\end{tabular}

LDW: leaf dry weight; SDW: stem dry weight; RDW: Roots dry weight; TDW: total dry weight. ns: not significant. Means in the same column with different letters indicate significant differences (LSD, $\mathrm{p}<0.05$ ). 
Table 3. Growth parameters in seedlings of melon Inodorus var. Honeydew at 50 days of planting, inoculated with $G$. intraradices.

\begin{tabular}{lccccc}
\hline \multirow{2}{*}{ Treatments } & \multicolumn{5}{c}{ Parameters } \\
\cline { 2 - 5 } & $\mathrm{SD}(\mathrm{cm})$ & $\mathrm{PH}(\mathrm{cm})$ & $\mathrm{EI}$ & $\mathrm{LS}\left(\mathrm{cm}^{2}\right)$ & $\mathrm{N}^{\circ}$ de hojas \\
\hline T0 & $0.43 \mathrm{a}$ & $16.76 \mathrm{a}$ & $39.46 \mathrm{~b}$ & $80.1 \mathrm{a}$ & $5.6 \mathrm{a}$ \\
$\mathrm{T} 1$ & $0.45 \mathrm{a}$ & $12.28 \mathrm{a}$ & $27.49 \mathrm{a}$ & $62.89 \mathrm{a}$ & $5.6 \mathrm{a}$ \\
T2 & $0.53 \mathrm{a}$ & $13.32 \mathrm{a}$ & $25.89 \mathrm{a}$ & $82.71 \mathrm{a}$ & $6.0 \mathrm{a}$ \\
T3 & $0.46 \mathrm{a}$ & $14.72 \mathrm{a}$ & $32.62 \mathrm{ab}$ & $72.55 \mathrm{a}$ & $5.2 \mathrm{a}$ \\
$\mathrm{p}$ & $\mathrm{ns}$ & $\mathrm{ns}$ & 0.0340 & $\mathrm{~ns}$ & $\mathrm{~ns}$ \\
\hline
\end{tabular}

SD: Stem diameter; PH: Plant height; EI: Etiolation index (PH/SD); LS: Leaf surface; ns: not significant. Means in the same column with different letters indicate significant differences (LSD, $\mathrm{p}<0.05$ ).

of the parameters measured, the plants inoculated with 40 spores* plant $^{-1}$ had the best response in the parameters of growth and differentiation, except for plant height (Table 3).

Although the differences in number of leaves, leaf surface and stem diameter were not significant, mycorrhization appeared to stimulate the growth of these parameters. An increase in stem diameter was observed in plants of Poncirus trifoliata $(\mathrm{Wu}$ et al., 2010), Cucumis melo (Huang et al., 2011), Leucaena leucocephala (Flores-Bello et al., 2008), Lycopersicum esculentum (He et al., 2010) and Calocedrus decurrens (Amaranthus and Steinfeld, 2005) when inoculated with mycorrhizae. Preciado et al. (2002) suggested that stem diameter is a good indicator of plant vigor, since it reflects directly the accumulation of photosynthates which after transplantation can be translocated to the demand sites. This was confirmed by Ortiz et al. (2009), who indicated that a thicker stem implies greater phloem area and thus more efficient transport and a greater reserve capacity of photosynthates. Mycorrhization generated a lower etiolation index, favoring better plant architecture; these characteristics are desirable to obtain seedlings with a better capacity to support transplant (Preciado et al. 2002).

\section{Indicators of stress}

The stress indicator most sensitive to mycorrhizal activity was the relation RDW/SDW and not SLF, since the former considers the behavior of the root where the symbiotic action occurs. Plants inoculated with Glomus intraradices had less stress than those not inoculated, since they had a greater RDW/SDW. The plants inoculated with 40 spores plant $^{-1}$ showed less stress $(0.33)$ than those inoculated with 20 or 80 spores* plant $^{-1}$, due to greater root weight (Table 4).

Our results are coincident with those obtained by Tobar et al. (1994) in lettuce, Meddad-Hamza et al. (2010) in micropropagated olives, Lee and Kim (2004) in cucumber and Oseni et al (2010) in tomato; these authors all reported an increase in the ratio RDW/SDW in plants with mycorrhizae, showing a high degree of efficiency of these fungi. This indicates that seedlings with mycorrhizae had a better value for this stress indicator and a better condition to support transplant, since they produced plants with better equilibrium between plant height and stem diameter.

\section{Enzymatic activity of nitrate reductase}

The enzymatic activity of nitrate reductase in leaves was not affected by the activity of Glomus intraradices in the inoculated plants (Table 5). All

Table 4. Indicators of stress in melon seedlings Inodorus var. Honeydew inoculated with $G$. intraradices 50 days after sowing.

\begin{tabular}{lcc}
\hline \multirow{2}{*}{ Treatments } & \multicolumn{2}{c}{ Parameters } \\
\cline { 2 - 3 } & SLS & RDW/SDW) \\
\hline T0 & $184.84 \mathrm{a}$ & $0.14 \mathrm{a}$ \\
T1 & $194.31 \mathrm{a}$ & $0.26 \mathrm{~b}$ \\
T2 & $171.09 \mathrm{a}$ & $0.33 \mathrm{c}$ \\
$\mathrm{T} 3$ & $176.54 \mathrm{a}$ & $0.27 \mathrm{~b}$ \\
$\mathrm{p}$ & $\mathrm{ns}$ & 0.0001 \\
\hline
\end{tabular}

SLS: Specific leaf surface (LS/LDW); R (LDW/SDW): (Root dry weight/Stem dry weight); ns: not significant. Means in the same column with different letters indicate significant differences (LSD, p < 0.05). 


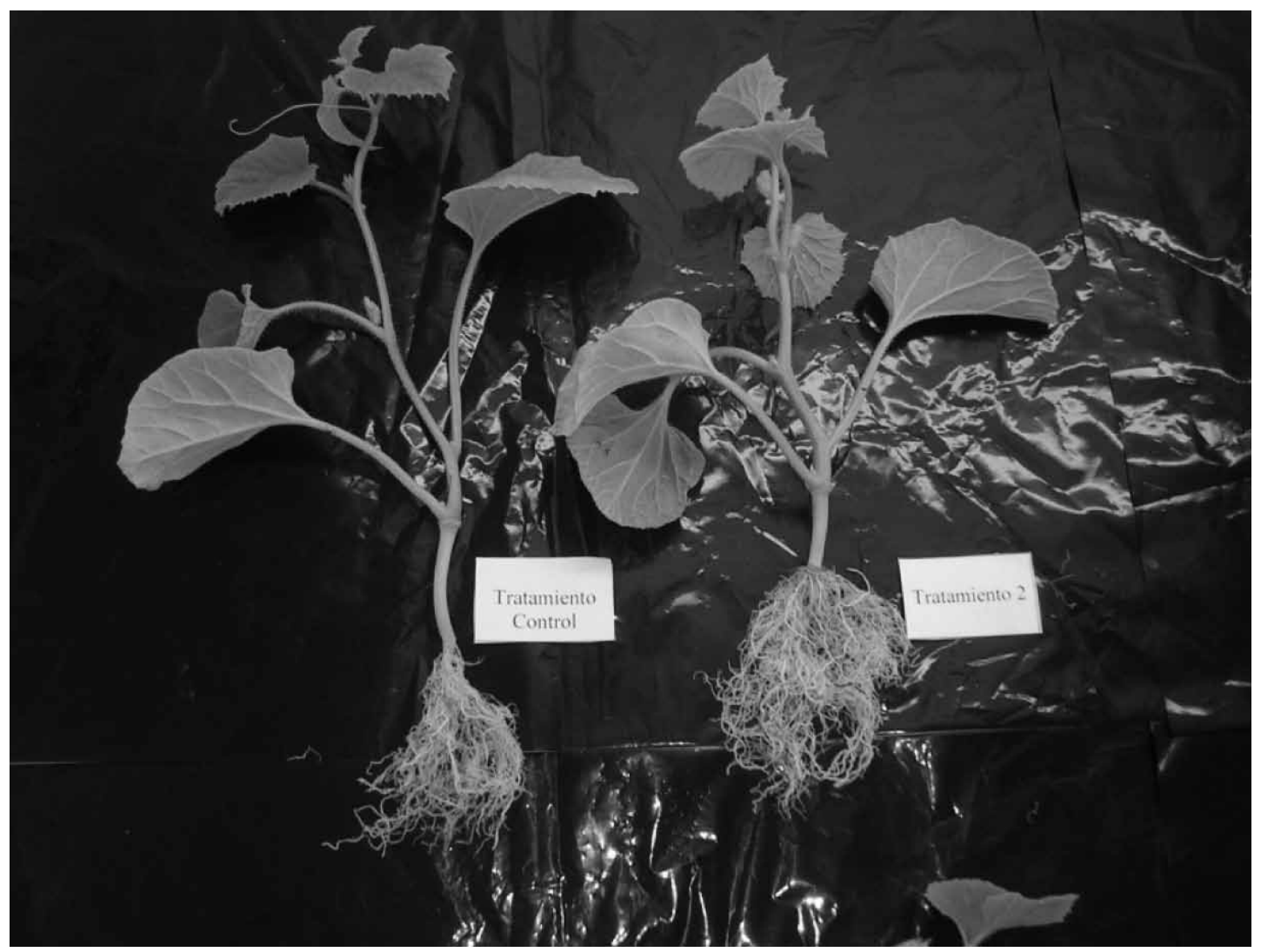

Figure 3. Comparison between the plants without inoculation (left) and with treatment $T_{2}$ (right).

Table 5. Nitrate reductase activity in seedlings of melon Inodorus var. Honeydew inoculated with G. intraradices at 50 days of sowing.

\begin{tabular}{lccc}
\hline & \multicolumn{2}{c}{ Parameters } \\
\cline { 2 - 3 } Treatments & $\mathrm{NRE}$ & $\mathrm{NRI}$ & NRI/NRE \\
\cline { 2 - 3 } & $\left(\mu \mathrm{Mde} \mathrm{NO}_{2-} \mathrm{g}^{-1} \mathrm{pf} \mathrm{h}^{-1}.\right)$ & & $\left(\mu \mathrm{M} \mathrm{de} \mathrm{NO}_{2-} \mathrm{g}^{-1} \mathrm{pf} \mathrm{h}^{-1}.\right)$ \\
\hline $\mathrm{T} 0$ & $1.52 \mathrm{a}$ & $1.53 \mathrm{a}$ & $1.01 \mathrm{a}$ \\
$\mathrm{T} 1$ & $1.47 \mathrm{a}$ & $1.59 \mathrm{a}$ & $1.18 \mathrm{a}$ \\
$\mathrm{T} 2$ & $1.29 \mathrm{a}$ & $1.58 \mathrm{a}$ & $1.24 \mathrm{a}$ \\
$\mathrm{T} 3$ & $1.12 \mathrm{a}$ & $1.54 \mathrm{a}$ & $1.39 \mathrm{a}$ \\
$\mathrm{p}$ & $\mathrm{ns}$ & $\mathrm{ns}$ & $\mathrm{ns}$ \\
\hline
\end{tabular}

NRE: Endogenous Nitrate Reductase; NRI: Induced Nitrate Reductasa. ns: not significant. Means in the same column with different letters indicate significant differences (LSD, $\mathrm{p}<0.05)$.

treatments received 7.5 meq $\mathrm{L}^{-1} \mathrm{NO}_{3}^{-1}$ in the fertirrigation solution; however, there was a better NRI/ NRE ratio (Induced Nitrate Reductasa/Endogenous Nitrate Reductase) $\left(\mathrm{T}_{1}: 18 ; \mathrm{T}_{2}: 24\right.$ y $\left.\mathrm{T}_{3}: 39 \%\right)$, which indicates a greater availability of $\mathrm{NO}_{3}^{-1}$ in the leaf tissue which may be reduced by the enzyme nitrogen reductase compared to the control. This indicates a certain level of abiotic stress present in seedlings with mycorrhizae, and concurs with the proposal of Tobar et al. (1994). The greater availability of $\mathrm{NO}_{3}{ }^{-1}$ in plants with mycorrhizae is explained because part of the nitrate was absorbed in the soil by the external mycelia of the fungi and reduced (Bago et al. 1996 y Johansen et al. 1996), allowing the 


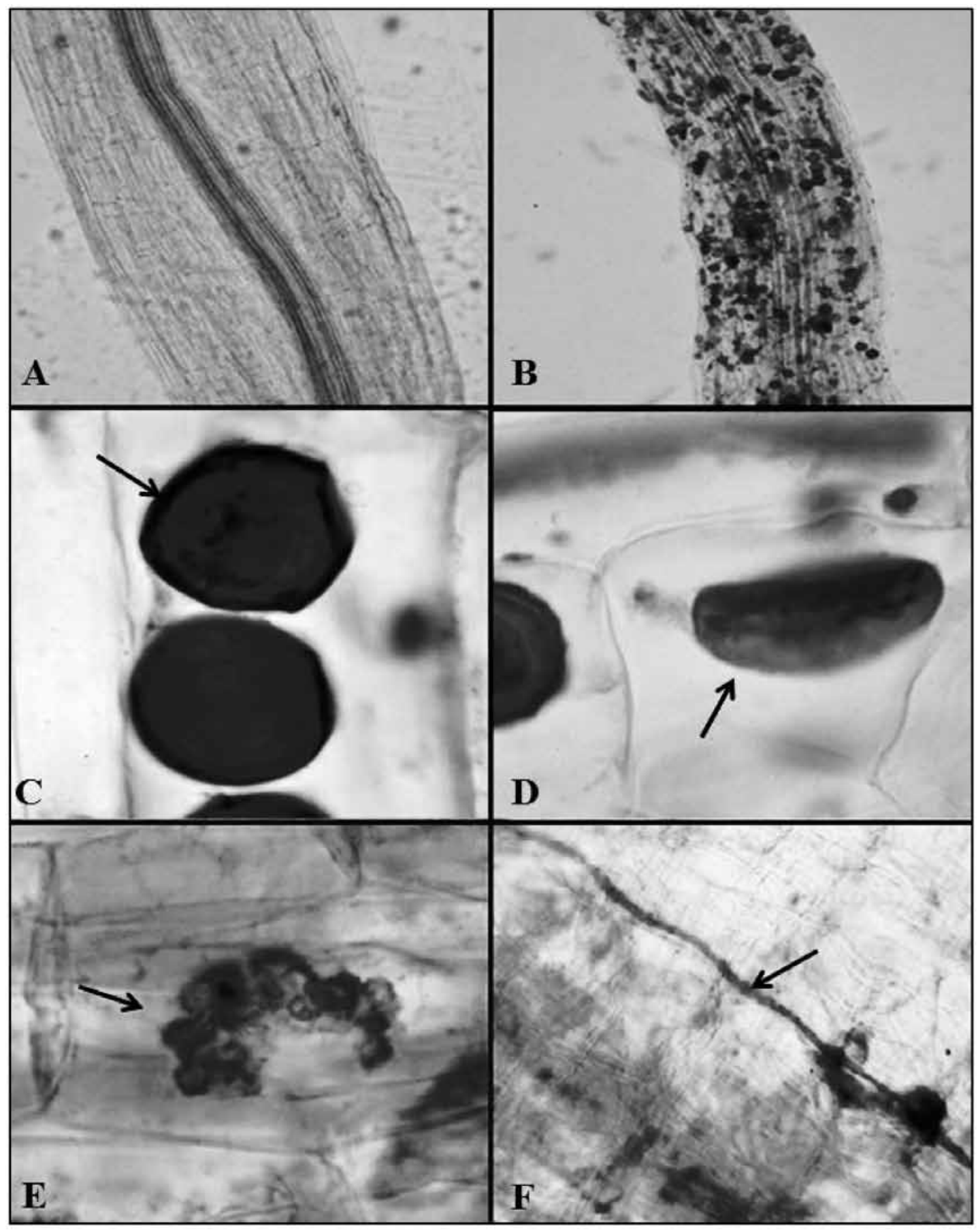

Figure 4. Fungal structures of Glomus intraradices colonizing the roots, staining with Tripan blue. A: Non-mycorrhized roots $\mathrm{T}_{0}$ (40X); B: Mycorrhized roots T 2 (40X); C: Spores (100X); D: Vesicles (100X); E: Arubuscles (100X); F: Intraradical mycelium (100X).

formation of intermediate molecules of the nitrogen cycle which are transferred to the plant for protein synthesis (Tilak and Dwivedi 1990, Subramanian and Charest 1998).

\section{Conclusions}

The inoculation at sowing with Glomus intraradices produced more equilibrated seedlings of 
honeydew melon, with a greater root development than non-inoculated plants, a lower etiolation index and greater availability of nitrates in the leaves for reduction by nitrate reductase. The dose of 40 spores $^{*}$ plant $^{-1}$ produced the greatest percentage of mycorrhization (49\%), a lower level of stress due to greater production of root biomass and $24 \%$ more nitrogen available for reduction in the leaves.

\section{Acknowledgements}

Centro de Investigación Avanzada en Recursos Hídricos y Sistemas Acuosos (CIDERH) CONICYTREGIONAL R09I1001. Departamento de Agricultura del Desierto y Biotecnología of the Universidad Arturo Prat State of Chile. Bio Triton Chile, for their support of this research by supplying the product MYCOSYM Tri-Ton.

\section{Literature Cited}

Amaranthus, M. y Steinfeld, D.

2005 Arbuscular mycorrhizal inoculation following biocide treatment improves Calocedrus decurrens survival and growth in nursery and out planting sites. Department of Agriculture, Forest Service, Rocky Mountain Research Station, pp. 103-108.

Avis, T.; Gravel, V.; Antoun, H. y Tweddell, R.

2008 Multifaceted beneficial effects of rhizosphere microorganisms on plant health and productivity. Soil Biology \& Biochemistry, 40 (7): 1733-1740.

Anaya, K.; Castillo, A.; Vega, G.; González, L. y Tamayo, E. 2009 Efecto de la inoculación del EcoMic sobre el desarrollo de las plántulas del cultivo del tomate (Lycopersicum esculentum Mill) bajo cultivos protegidos en el municipio Bayamo. Revista Electrónica Granma Ciencia, 13 (2): 1-11.

Azcón-Aguilar, C.; Barea, J.M.

1980 “Micorrizas". Investigación y Ciencia, 47: 8-16.

Bago, B.; Vierheilig, H.; Piché, Y. y Azcón-Aguilar, C.

1996. Nitrate depletion and $\mathrm{pH}$ changes induced by the extraradical mycelium of the arbuscular mycorrhizal fungus Glomus intraradices grown in monoxenic culture. New Phytologist, 133: 273-280.

Brundrett, M.C.

2002 Coevolution of roots and mycorrhizal of land plants. New Phytologist, 154: 275-304.

Casas, A.

2005 Factores implicados en el desarrollo de las plántulas: Fertilización. pp. 137-165. En: Cuadrado, I.; García, $M^{\mathrm{a}}$ del Carmen y Fernández, M. (eds.), Dirección Técnica de Semilleros Hortícolas, Curso de Especialización FIAPAASEHOR N ${ }^{\circ}$, Almería, España.

Drew, E.A.; Murray, R.R. y Smith, S.E.

2006 Functional diversity of external hyphae of AM fungi: ability to colonize new hosts is influenced by fungal species, distance and soil conditions. En The Mycota: A Comprehensive Treatise on Fungi as Experimental Systems for Basic and Applied Research, Environmental and Microbial Relationships. Second edition. Volume IV. Editors: Kubicek y Druzhinina. $350 \mathrm{pp}$.

Flores-Bello, M.; Aguilar-Espinosa, S.; García, R.; Zamora, A.;

Farías-Larios, J.; López-Aguirre, J.

2008 Inoculación con hongos micorrícicos arbusculares y el crecimiento de plántulas de Leucaena. Terra Latinoamericana, 26 (2): 127-131.
González-Monterrubio, C.; Monroy-Ata, A.; García-Amador, E. y Orozco-Almanza, M.

2005 Influencia de hongos micorrizógenos arbusculares (HMA) en el desarrollo de plántulas de opuntia Streptacantha Lem. sometidas a sequía, en condiciones de invernadero. Revista Especializada en Ciencias Químico-Biológicas, 8 (1): 5-10

Harley, J. y Smith, S.E.

1983 Mycorrhizal symbiosis. Academic. Press. Londres. 483 pp.

He, Z.; Tang, H.; Li, H.; He, Ch.; Zhang, Z. y Wang, H.

2010 Arbuscular mycorrhizal alleviated ion toxicity, oxidative damage and enhanced osmotic adjustment in tomato subjectd to $\mathrm{NaCl}$ stress. American-Eurasian Journal Agriculture and Environmental Science, 7 (6): 676-683.

Huang, Z.; Zou, Z.; He, C.; He, Z.; Zhang, Z. y Li, J.

2011 Physiological and photosynthetic responses of melon (Cucumis melo L.) seedling to three Glomus species under water deficit. Plant and Soil, 339 (1-2): 391-399.

Johansen, A.; Finlay, R. D. y Olsson, P.A.

1996 Nitrogen metabolism of external hyphae of the arbuscular mycorrhizal fungus Glomus intraradices, New Phytologist, 133, 705-712

Lee, Y-J. y Kim, T.-W.

$2004 \mathrm{Zn}$ Acquisition by Extrarradical Hyphae in Arbuscular Mycorrhizal Plant Depending on Zn Nutritional Status of Cucumber (Cucumis sativus L.) cv. Baekdadagi. Korean Journal of Environmental Agriculture, 23 (4): 191-196.

Martinez-Media, A.; Roldán, A. y Pascual, J.

2011 Interaction between arbuscular mycorrhizal fungi and Trichoderma harzianum under conventional and low input fertilization field condition in melon crops: Growth response and Fusarium wilt biocontrol. Applied Soil Ecology, 47: 98-105.

Meddad-Hamza, A.; Beddiar, A.; Gollotte, A.; Lemoine, M.; Kuszala, C. y Gianinazzi, S.

2010 Arbuscular mycorrhizal fungi improve the growth of olive trees and their resistance to transplantation stress. African Journal of Biotechnology, 9 (8): 1159-1167.

Mujica, Y. y Medina, N.

2008 Respuesta del tomate (Solanum lycopersicum L.) a la formulación líquida de cuatro cepas de Glomus en condiciones de campo. Cultivos Tropicales, 29 (3): 23-25. 
Oseni, T.; Shongwe, N. y Masarirambi, M.

2010 Effect of Arbuscular Mycorrhiza (AM) Inoculation on the Performance of Tomato Nursery Seedlings in Vermiculite. International Journal of Agriculture \& Biology, 12: 789-792.

Ortiz, J.; Sánchez, F.; Mendoza, M. y Torres, A.

2009 Características deseables de plantas de pepino crecidas en invernadero e hidroponía en altas densidades. Revista Fitotecnia Mexicana, 32 (4): 289-294.

Pereira, G.; Roldán, I. y Herrera, M.

1999 Micorrizas en especies leñosas. Consejería de Agricultura y Pesca Dirección General de Investigación y Formación Agraria. Junta de Andalucía. España. 40 pp.

Phillips, J. y Hayman, D.

1970 Improved procedures for clearing roots and staining parasitic and vesicular arbuscular mycorrhizal fungi for rapid assessment of infection. Transactions of the British Mycological Society, 55: 158-161.

Preciado, P.; Baca, G.; Tirado, J.; Kahashi-Shibata, J.; Tijerina,

L. y Martinez, A.

2002 Nitrógeno y potasio en la producción de plántulas de melón. Terra Latinoamericana. 20 (3): 267-276.

Smith, F.; Jakobsen, I. y Smith, S.E.

2001 Spatial differences in acquisition of soil phosphate between two arbuscular mycorrhizal fungi in symbiosis with Medicago trunctula. New Phytologist, 147: 357-366.

Subramanian; K.S. y Charest, C.

1998 Acquisition of $\mathrm{N}$ by external hyphae of an arbuscular mycorrhizal fungus and its impact on physiological responses in maize under drought-stressed and well-watered

Tesi, R. conditions. Mycorrhiza 9: 69-75.

1991 Principi di orticoltura e ortaggi d'Italia. Ed. Edagricole. Bolonia. 346 pp.
Tilak, K. y Dwivedi, A.

1990 Nitrate reductase activity of vesicular-arbuscular mycorrhizal fungi. Haryana Agricultural University. India. 59-60 pp.

Tobar, R.; Azcón, R., Barea J.M.

1994 Improved nitrogen uptake and transport from ${ }^{15} \mathrm{~N}$ labeled nitrate by external hyphae of arbuscular Mycorrhiza under water-stressed conditions. New Phytologist, 126: 119-122.

Trouvelot, A.; Kough, J.L; Gianinazzi-Pearson. V.

1986 Mesure du taux de mycorrhization VA d'un système radiculaire. Recherche de methods d'estimation ayant une signification fonctionelle. En: 'Physiological and genetical aspects of mycorrhizae'. Gianinazzi-Pearson, V. and Gianinazzi, S. eds., INRA, Paris, pp. 101-109.

Valenzuela, J.L.; Sánchez, A.; Romero, L.

1987 Assesing critical N supply by means of nitrate-reductase activity in tomato and cucumber plants. Journal of Plant Nutrition, 10: 1733-1741.

Wang, R.; He, C.; Wang, H. y Zhang, Z.

2010 Effect of am fungi on the yield and nutrient quality of different muskmelon varieties in greenhouse. Acta Horticulturae Sinica. 37 (11): 1767-1774.

Wu, Q.-S.; Xia, R.-X. y Zou, Y.-N.

2006 Reactive oxygen metabolism in mycorrhizal and non-mycorrhizal citrus (Poncirus trifoliata) seedling subjected to water stress. Journal of Plant Physiology, 163: 1101-1110.

Wu, Q.S.; Zou, Y.N.; Liu, W.; Ye, X.F.; Zai, H.F. y Zhao, L.J. 2010 Alleviation of salt stress in citrus seedlings inoculated with Mycorrhiza: changes in leaf antioxidant defense systems. Plant Soil Environ, 56 (10): 470-475. 
